PEDAGOGIA : Jurnal Ilmu Pendidikan

\title{
PENGGUNAAN MEDIA FLASHCARD UNTUK MENINGKATKAN PENGENALAN BENTUK HURUF SISWA KELAS I PADA MATA PELAJARAN BAHASA INDONESIA DI SEKOLAH ABC MANADO
}

\author{
Rahel Ika Primadini Maryanto, Imanuel Adhitya Wulanata Chrismastianto \\ SD Sekolah Palembang Harapan \\ rahel.maryanti@sdh.pr.id
}

\begin{abstract}
Abstrak
Berdasarkan hasil observasi selama tiga minggu dan hasil tes diagnostik yang dilaksanakan pada mata pelajaran Bahasa Indonesia, menunjukkan pengenalan bentuk huruf pada siswa kelas 1 masih terbatas. Tujuan dari penelitian ini adalah meningkatkan pengenalan bentuk huruf pada siswa dengan menggunakan media flashcard. Penelitian yang digunakan adalah Penelitian Tindakan Kelas (PTK) model Kemmis dan Taggart, yang berlangsung selama dua siklus. Penelitian dilaksanakan pada tanggal 24 Juli hingga 25 Oktober 2017 terhadap 6 siswa sebagai subyek penelitian, di Sekolah ABC Manado. Instrumen yang digunakan selama penelitian adalah lembar tes tertulis (tes diagnostik dan tes formatif), lembar observasi chekcklist penggunaan media, lembar wawancara (guru mentor dan subyek penelitian), dan jurnal refleksi.Hasil penelitian menunjukkan peningkatan pengenalan bentuk huruf kelas 1 Sekolah ABC Manado pada mata pelajaran Bahasa Indonesia di setiap indikator, dari siklus satu ke siklus 2. Masing-masing peningkatan indikator adalah 5,21\% untuk indikator $\mathrm{PBH}-1,12,53 \%$ untuk indikator PBH2 , dan 25\% untuk indikator PBH-3. Maka disimpulkan bahwa penggunaan media flashcard dapat meningkatkan pengenalan bentuk huruf siswa kelas 1 pada mata pelajaran Bahasa Indonesia di sekolah ABC Manado.
\end{abstract}

Kata Kunci: Media Flashcard; Pengenalan Bentuk Huruf; Siswa; Bahasa Indonesia

\begin{abstract}
Based on the observation for three weeks and diagnostic test result in Indonesian language subject, it is proven that the students in $1^{\text {st }}$ grade of $A B C$ 's School Manado have not yet fully understood alphabet form. The purpose of this research is to enhance the alphabet form recognition on students who become the subject of research by used flashcard media. The research method used in this research was a Classroom Action Research (CAR) Kemmis and Taggart's model, held in two cycles. The research was conducted on July $24^{\text {th }}$ until October $25^{\text {th }}, 2017$ towards 6 students, in ABC's School Manado. Instruments used in this research were written test sheet (diagnostic test and formative test), observation check list media usage, interview sheet (mentor and students as research subjects), and reflection journal. Based on the research that has been done, it showed the increased of the alphabet form recognition on $1^{\text {st }}$ grade students of $A B C$ 's School Manado, in every indicators from first cycle to second cycle. The enhanced each of indicators are 5,21\% for indicator $P B H$ $1,12,53 \%$ for indicator $\mathrm{PBH}-2$, and $25 \%$ for indicator $\mathrm{PBH}-3$. It is concluded that the use of flashcard media can enhance alphabet form recognition students of the $1^{\text {st }}$ grade in Indonesian language subject of $A B C$ 's School Manado.
\end{abstract}

Keywords: Flashcard Media; Alphabet Form Recognition; Student; Indonesian Language 
PEDAGOGIA : Jurnal IImu Pendidikan

\section{A. PENDAHULUAN}

Salah satu kemampuan berbahasa yang penting bagi anak adalah kemampuan membaca dan menulis, yang diawali dengan pengenalan huruf pada masa Taman Kanak-Kanak (Hanum \& Pangastuti, 2017). Hal tersebut didukung oleh sasaran perkembangan bahasa pada Taman Kanak-Kanak di Indonesia, menurut Pudjaningsih (2013) bahwa kemampuan mengenal lambang huruf, merupakan tingkat pencapaian perkembangan yang harus dicapai anak usia 4-5 tahun. Pada usia tersebut juga, seharusnya anak sudah mampu untuk meniru huruf. Berdasarkan hasil observasi, wawancara siswa maupun guru mentor, dan hasil tes diagnostik, menunjukkan bahwa beberapa siswa kelas 1 masih belum mengenal bentuk huruf dengan baik.

Usia kelas 1 SD berada dalam rentang 5-7 tahun. Menurut Piaget (dalam Syah, 2009), pada usia tersebut, anak masuk pada tahap pra operasional. Djiwandono (2002) menjelaskan bahwa pada usia ini, siswa masih memiliki pikiran yang egosentris dan berpusat. Adapun kemampuan berbahasa yang dimiliki oleh anak usia 6 tahun adalah menulis huruf dengan ketepatan dan minat dari huruf kecil sampai huruf besar (Allen \& Marotz, 2010). Anak perlu pembiasaan dalam menulis huruf karena terkadang bisa terbalik atau bingung dengan beberapa huruf: $b / d, p / g, g / q, t / f$ (Allen $\&$ Marotz, 2010). Jika masalah ini tidak diatasi, siswa akan sangat kesulitan untuk melangkah kepada tahap selanjutnya yaitu untuk membaca dan menulis.

Menulis merupakan keterampilan penting yang ditinjau dari perspektif Alkitab. Menulis haruslah jelas dan dapat terbaca (Haycock, 1993). Hal ini dapat dilihat dalam Ulangan 27:8. Menurut tafsiran Alkitab (Tafsiran Alkitab, 2000), dijelaskan bahwa hukum-hukum Tuhan harus ditulis dengan jelas dan terang, sehingga hukum itu dapat dibaca dan dimengerti dengan mudah. Allah sendiri mengajarkan tentang pentingnya menulis dengan jelas dan terbaca, supaya orang yang membaca tulisan tersebut memahami, apa yang ingin diungkapkan oleh penulis. Maka dari itu, pengenalan bentuk huruf yang benar kepada siswa penting agar siswa dapat menghasilkan tulisan yang jelas dan dapat terbaca. Hal ini juga telah dibuktikan oleh penelitian sebelumnya dari Ratna Pangastuti dan Siti Farida Hanum (2017) mengenai Pengenalan Abjad Pada Anak Usia Dini Melalui Media Kartu Huruf, yang membuktikan bahwa, penggunaan media flashcard (dalam penelitian tersebut disebutkan sebagai kartu huruf) lebih mempermudah menyampaikan pesan pembelajaran untuk mengenal huruf melalui pengalaman yang bermakna.

\section{B. TINJAUAN PUSTAKA}

\section{Media Flash Card}

Media sangat penting bagi siswa 
PEDAGOGIA : Jurnal Ilmu Pendidikan

dalam belajar karena media dapat mempelajari pesan selain ceramah yang disampaikan oleh guru, dapat mengakomodir daya indera, meminimalisir keterbatasan ruang dan waktu, mengatasi sikap pasif, dan siswa menjadi lebih bergairah dan mengkombinasikan munculnya persamaan persepsi dari pengalaman (Arief, dkk, 2009). Media flashcard adalah media pembelajaran dalam bentuk kartu bergambar yang ukurannya sekitar $25 \times 30 \mathrm{~cm}$. Gambar yang ada pada media ini merupakan rangkaian pesan yang disajikan dengan keterangannya (Indriana, 2011). Sedangkan Chatib (2011), menjelaskan bahwa media flashcard adalah kartu yang berisi gambar atau tulisan berhubungan dengan konsep. Definisi lain diungkapkan oleh Windura (2010), bahwa media flashcard atau kartu kilas adalah kartu yang digunakan untuk mengingat dan mengkaji ulang dalam proses belajar. Jadi, media flashcard merupakan media yang membantu dalam mengingat dan mengkaji ulang bahan pelajaran seperti: definisi atau istilah, simbol-simbol, ejaan bahasa asing, rumus-rumus, dan lain-lain.

Kelebihan media flashcard yang dijelaskan oleh Indriana (2011) dan Riyana dan Susilana (2009) yang pertama adalah mudah dibawa kemana-mana karena ukurannya yang tidak besar dan ringan. Kedua adalah praktis dalam membuat dan menggunakanya, sehingga kapan pun anak didik bisa belajar dengan baik menggunakan media ini. Ketiga, media flashcard juga gampang diingat karena kartu ini bergambar dan sangat menarik perhatian, memuat huruf atau angka yang simpel, sehingga merangsang otak untuk lebih lama mengingat pesan yang ada. Media ini sangat menyenangkan untuk digunakan sebagai media pembelajaran, bahkan dapat digunakan dalam bentuk permainan. Selain kelebihan di atas Hotimah (2010) juga menyatakan bahwa keunggulan dari media flashcard adalah membantu kemampuan otak kanan untuk mengingat gambar dan kata-kata sebagai komponennya. Melalui pendapat beberapa ahli di atas maka kelebihan media flashcard adalah mudah dibawa, praktis, gampang diingat, dan menyenangkan.

Adapun karakteristik media flashcard ideal yang dikemukakan oleh beberapa ahli. Karakteristik media flashcard yang dikemukakan oleh Indriana (2011) yang pertama, ukuran flashcard sekitar $20 \times 30 \mathrm{~cm}$. Kedua gambar yang disajikan berhubungan dengan materi pembelajaran. Ketiga media ini digunakan untuk kelompok kecil kurang lebih 25 orang. Adapun karakteristik media flashcard yang efektif menurut Pujiati (2017) yaitu, memuat tampilan huruf dalam ukuran cukup besar dan berwarna mencolok dengan latar polos, kontras dibandingkan warna huruf. Berdasarkan pendapat beberapa ahli di atas, maka dapat disimpulkan bahwa karakteristik media flashcard merupakan 
PEDAGOGIA : Jurnal Ilmu Pendidikan

kartu kombinasi antara tulisan dan gambar yang berhubungan dengan materi pelajaran, dibuat secara proporsional, dan ukurannya dapat disesuaikan dengan ruang dan jumlah siswa.

\section{Pengenalan Bentuk Huruf}

Rislina dan Khan (2015) menjelaskan bahwa untuk bisa membaca, terlebih dahulu anak menghafalkan semua bentuk huruf kecil dan huruf besar, yang dilakukan pada masa taman kanak-kanak (TK). Mengenal bentuk huruf berarti mengerti perbedaan-perbedaan antara huruf (Allen \& Marotz, 2010). Gibson (1964, dalam Wasik, 2008) lebih jelas menjabarkan suatu penelitian, bahwa untuk mengerti perbedaan bentuk huruf, anak telebih dahulu mencirikan bentuk berbeda dari huruf-huruf. Melalui penjelasan di atas, disimpulkan bahwa pengenalan bentuk huruf adalah tahap dimana siswa memahami hubungan nama dan bentuk huruf yang sesuai.

Bentuk huruf merupakan lambang atau simbol dan media flashcard merupakan salah satu bentuk media visual. Levie dan Levie (1975, dalam Arsyad 2004) mengidentifikasi suatu penelitian tentang belajar melalui stimulus gambar dan stimulus kata atau visual, seperti guru menjelaskan materi menggunakan suatu media. Levie dan Levie menyimpulkan bahwa stimulus visual membuahkan hasil belajar yang lebih baik untuk mengingat, mengenali, dan menghubung-hubungkan fakta dan konsep. Di luar pihak stimulus verbal juga mendukung apabila pembelajaran melibatkan ingatan yang berurut-urutan (sekuensial). Lebih lanjut Levie dan Levie menjelaskan bahwa ini merupakan bukti dari konsep hipotesis koding ganda, yang mengatakan bahwa ada dua sistem ingatan manusia. Satu untuk mengolah simbolsimbol verbal kemudian menyimpannya dalam bentuk proposisi gambar, dan yang lainnya untuk mengolah gambar nonverbal kemudian disimpan dalam bentuk propisisi verbal. Ketika membaca flashcard huruf, siswa akan menggunakan indera ganda yaitu indera pandang dan dengar. Arsyad (2004) menjelaskan bahwa belajar menggunakan indera gandapandang dan dengar- berdasarkan konsep yang dijelaskan Levie dan Levie akan memudahkan siswa belajar lebih banyak dari pada hanya dengan stimulus pandang atau stimulus dengar saja. Ditinjau dari perkembangan anak pada usia 6 tahun, dalam hal perseptual-kognitif, anak mengandalkan kemampuan visual misalnya dalam hal mencocokan huruf dan kata dengan gambar (Allen \& Marotz, 2010). Hal ini sesuai dengan karakteristik media flashcard yang digunakan, di mana melalui media tersebut siswa dapat mencocokan gambar dengan bentuk huruf. Indikator yang diambil sebagai sasaran dari pengenalan bentuk huruf untuk siswa kelas 1 Sekolah ABC Manado pada mata pelajaran Bahasa Indonesia, yang pertama adalah menghubungkan bentuk huruf dengan namanya (Otto, 
PEDAGOGIA : Jurnal Ilmu Pendidikan

2015). Pencapaian dari indikator ini adalah ketika siswa dapat menuliskan bentuk huruf setelah guru menyebutkan nama bentuknya. Indikator yang kedua adalah mengenal huruf kapital atau huruf besar (Seefelt \& Wasik, 2008). Pencapaian dari indikator ini adalah ketika siswa dapat membedakan huruf kapital dari susunan huruf-huruf kapital dan huruf kecil. Selain itu, siswa juga dapat menuliskan huruf kapital yang diminta oleh guru. Sedangkan indikator yang ketiga adalah mengenal huruf kecil (Seefelt \& Wasik, 2008). Pencapaiaian dari indikator ini adalah siswa dapat membedakan huruf kecil dari susunan huruf-huruf kapital dan huruf kecil. Sama seperti indikator mengenal huruf besar, siswa juga dapat menuliskan huruf kecil yang diminta oleh guru dengan benar.

\section{METODE PENELITIAN}

Penelitian yang dilakukan merupakan penelitian tindakan kelas (PTK). Menurut Kemmis (1988, dalam Sanjaya, 2009) PTK adalah bentuk penelitian reflektif dan kolektif yang dilakukan dalam situasi sosial untuk meningkatkan penalaran praktik peneliti. Tujuan PTK menururt Trianto (2011) adalah memecahkan masalah, memperbaiki kondisi, mengembangkan dan meningkatkan mutu pembelajaran. Desain PTK yang dipilih oleh peneliti adalah desain PTK model Kemmis dan Mc Taggart, yang menggunakan empat tahap dan dilakukan secara berulang (spiral). Keempat tahap tersebut adalah rencana (planning), tindakan (acting), pengamatan (observing), refleksi (reflecting), dan perencanaan kembali yang merupakan dasar untuk suatu ancang-ancang pemecahan permasalahan (Trianto, 2011). Keempat tahapan tersebut dilaksanakan dalam satu siklus. Penelitian ini berlangsung di kelas 1 Sekolah ABC Manado pada mata pelajaran Bahasa Indonesia. Dalam penelitian ini, peneliti menggunakan teknik purposive sampling. Teknik purposive sampling mengambil sampel yang disesuaikan dengan tujuan penelitian (Taridala, 2010). Tujuan dari penelitian ini adalah membantu siswa mengenal bentuk huruf, sehingga penelitian ini dilakukan hanya untuk siswa kelas 1 yang masih belum bisa mengenal huruf. Peneliti melakukan tes kemampuan awal dan terambil 6 dari 30 siswa sebagai subyek penelitian. Siswa yang menjadi subyek penelitian merupakan siswa yang mendapat nilai tes kemampuan awal di bawah rata-rata. Subyek penelitian terdiri dari 4 siswa laki-laki dan 2 siswa perempuan. Penelitian ini berlangsung dari tanggal 24 Juli-25 Oktober 2017. Instrumen utama yang digunakan untuk melihat bagaimana penggunaan media flashcard dalam pembelajaran adalah check list observasi yang diisi oleh rekan sejawat dan guru mentor. Sedangkan, instrumen utama untuk mengukur pengenalan bentuk huruf adalah tes formatif yang dilaksanakan di akhir 
PEDAGOGIA : Jurnal Ilmu Pendidikan

pembelajaran. Adapun jurnal refleksi, wawancara guru mentor dan subyek penelitian digunakan sebagai instrumen pendukung. Peneliti mengambil kriteria ketuntasan indikator dengan taraf baik optimal yang dikemukakan oleh Djamarah dan Zain (2004, hal. 108) di mana apabila lebih dari $75 \%$ bahan pelajaran dapat dikuasai oleh siswa.

Pemberian nilai untuk hasil jawaban tes dihitung dari setiap indikator dengan perhitungan berdasarkan teknik penskoran, di mana "skor adalah hasil menjumlahkan angka-angka bagi setiap soal tes yang dijawab betul oleh siswa (Arikunto, 2010, hal. 235)." Setelah menghitung skor, kemudian akan menghitung nilai dengan penghitungan skoring standar mutlak (Sudijono, 2005, hal. 318) sebagai berikut:

\section{Tabel 1}

Interval Nilai, Kategori dan Makna

\begin{tabular}{ccc}
\hline $\begin{array}{c}\text { Interval } \\
\text { Nilai }\end{array}$ & Kategori & Makna \\
\hline $76-100$ & BS & Baik Optimal \\
$51-75$ & B & Baik \\
$26-50$ & C & Cukup \\
$<26$ & K & Kurang \\
\hline
\end{tabular}

\section{HASIL DAN PEMBAHASAN}

Berdasarkan hasil pengolahan data pada siklus 1 dan siklus 2, menunjukkan penggunaan media flashcard dapat meningkatkan indikator pengenalan bentuk huruf yang diujikan melalui tes formatif. Peningkatan tersebut dapat terlihat melalui diagram di bawah ini:

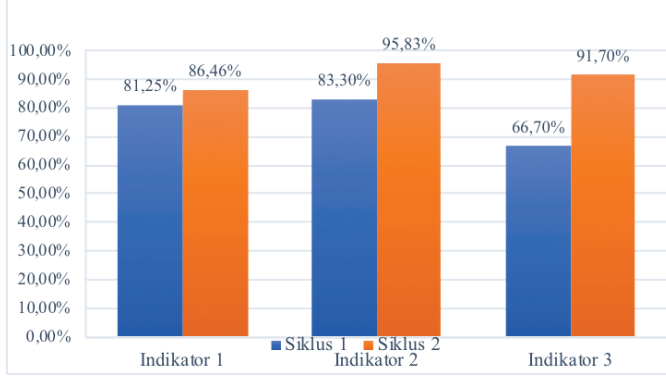

Gambar 1

Gambar Perbandingan Indikator Pengenalan

Bentuk Huruf Yang Dicapai Subyek Penelitian Lewat Tes Formatif Pada Siklus 1 dan Siklus 2

Pada indikator 1, terjadi peningkatan sebesar 5,21\%. Pada indikator 2 terjadi peningkatan sebanyak 13,53\%. Sedangkan pada indikator 3, terjadi peningkatan sebanyak 25\%. Pencapaian dari masing-masing indikator, telah mampu mencapai kriteria ketuntasan dengan taraf baik maksimal sesuai dengan pemaparan Djamarah dan Zain (2004), di mana bahan pelajaran yang dapat dikuasai oleh siswa mencapai lebih dari $75 \%$. Adapun peningkatan dari 6 subyek penelitian dapat dilihat pada diagram di bawah:

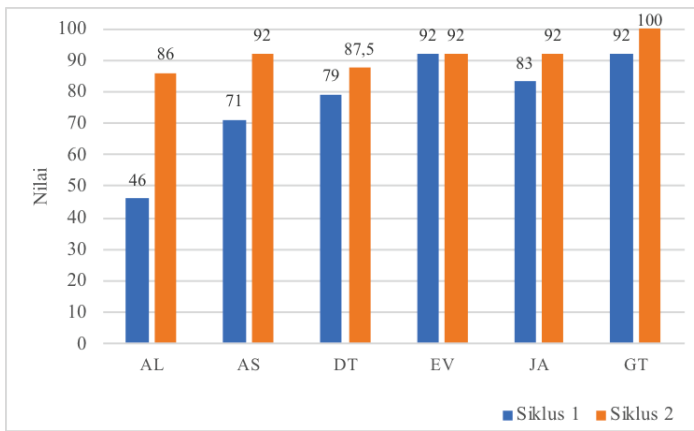

Gambar 2

Diagram Perbandingan Nilai Tes Formatif Siklus 1 dan Siklus 2 
PEDAGOGIA : Jurnal Ilmu Pendidikan

Peningkatan yang terjadi pada siklus satu dan dua ditunjang oleh karakteristik media flashcard yang sesuai tujuan pembelajaran. Aktivitas melihat media flashcard dan mendengar bunyi huruf yang dilakukan, membuat siswa lebih mudah mengenal bentuk huruf. Hal ini sesuai dengan teori yang diungkapkan oleh Levie dan Levie (1975, dalam Arsyad 2004) di mana stimulus visual membuahkan hasil yang lebih baik untuk mengingat, mengenali, dan menghubungkan suatu fakta dengan konsep. Penelitian ini juga membuktikan penjelasan dari Arsyad (2004) bahwa pembelajaran menggunakan media flashcard yang menggunakan indera ganda (pandang dan dengar) akan memudahkan siswa belajar lebih banyak daripada hanya dengan indera pandang atau indera dengar saja. Peneliti memutuskan untuk menghentikan penelitian karena setiap indikator dari pengenalan bentuk huruf sudah mencapai, bahkan melebihi indikator keberhasilan penelitian (75\%).

Penelitian yang dilakukan membuktikan bahwa peran guru sebagai seniman penting di dalam kelas. "Guruseniman menonjolkan pentingnya strategi mengajar yang kreatif dan respon dari siswa (Brummelen, 2009, hal. 35)." Kekreativitasan diwujudkan dalam bentuk media flashcard membuat siswa lebih mengenal bentuk huruf. Penelitian ini telah berhasil menggunakan media flashcard untuk menuntun siswa yang kesulitan dalam pengenalan bentuk huruf, sebagai wujud tanggung jawab sebagai seorang guru Kristen, yang menggunakan talenta mengajar untuk menyelesaikan permasalahan di dalam kelas.

\section{E. KESIMPULAN}

Penggunaan media flashcard dapat meningkatkan pengenalan bentuk huruf siswa kelas 1 pada mata pelajaran Bahasa Indonesia di Sekolah ABC Manado. Peningkatan dapat diamati melalui persentase pencapaian indikator menghubungkan bentuk huruf dengan namanya $86,46 \%$, indikator mengenal huruf kapital 95,83\%, serta indikator mengenal huruf kecil 91,7\%. Penggunaan media flashcard dapat meningkatkan pengenalan bentuk huruf siswa kelas 1 pada mata pelajaran Bahasa Indonesia, apabila media flashcard memiliki karakteristik yang sesuai tujuan pembelajaran, penerapan dengan aktivitas yang memungkinkan siswa untuk belajar sendiri menurut minat dan kemampuannya, serta penggunaan media flashcard yang difokuskan kepada siswa yang memerlukan peningkatan pengenalan bentuk huruf. Menjadi 'pembelajar' juga adalah fungsi penting dari sifat guru sebagai manusia yang terbatas, yang mengetahui bahwa segala sesuatu adalah bagi kemuliaan satusatunya yang tak terbatas: Tuhan (Issler \& Habermas, 2002). Melalui penelitian tindakan kelas yang dilaksanakan, peneliti 
PEDAGOGIA : Jurnal Ilmu Pendidikan

sebagai guru pengajar telah belajar, dan berhasil untuk berinovasi dalam pembelajaran menggunakan media flashcard, agar siswa dapat lebih mengenal bentuk huruf.

\section{DAFTAR PUSTAKA}

Allen, E., \& Marotz, L. (2010). Profil perkembangan anak. Jakarta: PT Indeks.

Arief S. Sadiman, dkk. (2009). Media pendidikan, pengertian, pengembangkan dan pemanfaatannya. Jakarta: Rajawali Press.

Arsyad, A. (2004). Media pembelajaran. Jakarta: PT Grafindo Persada.

Arikunto, S. (2010). Penelitian tindakan. Yogyakarta:Aditya Media.

Brummelen, v. H. (2009). Berjalan dengan Tuhan dalam kelas. Tangerang: Universitas Pelita Harapan.

Chatib, M. (2011). Gurunya manusia: menjadikan semua anak istimewa dan semua anak juara. Bandung: PT Mizan Pustaka.

Djamarah, S.B., Zain, A. (2004). Strategi belajar-mengajar. Jakarta: PT Rineka Cipta.

Djiwandono, S. E. W. (2002). Psikologi perkembangan. Jakarta: PT Grasindo.

Habermas, R., \& Issler, K. (2002). How we learn: A Christian teacher's guide to educational psychology.
Oregon: Baker Books.

Hanum, S. F., Pangastuti, R. (2017). Pengenalan abjad pada anak usia dini melalui media media flashcard huruf. Indonesian Journal of Early Childhood Islamic Education, 1(1), 51-66. 2550-1100.

Haycock. (1993). Encyclopedia of Bible truth. Colorado Springs: Purposeful Design Publication.

Hotimah. (2010). Penggunaan media flashcard dalam meningkatkan kemampuan siswa pada pembelajaran kosakata Bahasa Inggris kelas II MI Ar-Rochman Samarang Garut. Jurnal Pendidikan Universitas Garut, 4(1), 10-19. 1907-932XX.

Indriana, D. (2011). Ragam alat bantu media pengajaran. Jogjakarta: DIVAPress.

Otto, B. (2015). Perkembangan bahasa pada anak usia dini. Jakarta: PRENADAMEDIA GROUP.

Hanum, S. F., Pangastuti, R. (2017). Pengenalan abjad pada anak usia dini melalui media media flashcard huruf. Indonesian Journal of Early Childhood Islamic Education, 1(1), 51-66. 2550-1100.

Pudjaningsih, W. (2013). Pembelajaran melalui bermain dalam rangka pengembangan kemampuan berbahasa anak di TK Islam AlAzhar Kota Jambi. Jurnal PENA, 
3(1), 36-50. 2089-3973.

Pujiati, M. (2017). Cara mudah mengajar anak membaca: mengajari anak membaca menjadi ringan dan menyenangkan. Nauka Publishing Pangastuti, R., \& Hanum, S. F. (2017). Pengenalan Abjad pada Anak Usia Dini Melalui Media Kartu Huruf. Al-Hikmah: Indonesian Journal of Early Childhood Islamic Education, 1(1), 51-66.

Rislina, S. L., Khan, R. I. (2015). Mengenalkan huruf melalui loncat abjad pada anak usia 4-5 tahun. Nusantara of research journal, 2(02), 157-165. 2355-7249.

Riyana, C., \& Susilana, R. (2009). Media pembelajaran. Bandung: CV Wacana Prima.

Sanjaya, W. (2009). Penelitian Tindakan Kelas. Jakarta: Prenadamedia Group.

Seefelt, C., \& Wasik, A. (2008). Pendidikan anak usia dini: menyiapkan anak usia tiga, empat, dan lima tahun masuk sekolah. Jakarta: PT INDEKS.

Sudijono, A. (2005). Pengantar evaluasi pendidikan. Jakarta: PT Grafindo Persada

Syah, M. (2009). Psikologi Pendidikan. Bandung: PT Remaja Rosdakarya. Taridala, Y. (2010). Metode penelitian bagi pendidik. Jakarta: Multi Prestasi Satudelapan.

Trianto. (2011). Panduan lengkap penelitian tindakan kelas: teori dan praktik. Jakarta: Prestasi Pustakarya.

Windura, S. (2010). Memory Champion School: Rahasia mengingat materi pelajaran apa saja. Jakarta: PT Elex Media Komputindo. 